\title{
Research Paper Status of national agriculture market (eNAM) in Punjab
}

\section{- Lovepreet Singh and Mini Goyal}

See end of the paper for authors' affiliations

Correspondence to : Lovepreet Singh Department of Economics and Sociology, Punjab Agricultural University, Ludhiana (Punjab) India Email: lovepreetpau94@ gmail.com

Paper History :

Received : 04.06.2020;

Revised : 02.07.2020;

Accepted : 04.08 .2020
ABSTRACT : National Agriculture Market (eNAM) is a pan-India electronic trading portal which was introduced by the government of India in 585 Agriculture Produce Marketing Committees (APMCs) in 16 states and two Union Territories (UTs) till $31^{\text {st }}$ March 2018. The mission of eNAM is to integrate all the APMCs across the country through common online platform to facilitate farmers so that they can earn high income by selling their produce anywhere in the country. There was slow but definite increase in the adoption of eNAM by the stakeholders in India as well as in Punjab. Still about 12 per cent of total APMCs of Punjab has been integrated with eNAM. Since the implementation of eNAM in Punjab total seven commodities viz., potato, Basmati, maize, kinnow, Moong dal, cotton and green peas are traded through it. So far more than two lakh farmers, nearly 1400 traders and 5000 plus commission agents registered with portal have traded commodities worth Rs. 3686 crore involving 12.61 lakh tone of agriculture produce. The government of Punjab is on the right direction by implementing the policy of "One Nation One Market" for agricultural produce because both the quantity and value of trade is increased during the year 2019-20 as compared to 2018-19. It certainly helps in strengthens the existing system of agriculture marketing.

KEY WORDS : eNAM, Agriculture marketing

How To Cite This Paper : Singh, Lovepreet and Goyal, Mini (2020). Status of national agriculture market (eNAM) in Punjab. Internat. Res. J. Agric. Eco. \& Stat., 11 (2) : 118-126, DOI : 10.15740/HAS/IRJAES/11.2/ 118-126.Copyright@2020:Hind Agri-Horticultural Society. 